\title{
SIMULASI PENEMPATAN RORAK SEBAGAI BENTUK PENGOPTIMALAN KONSERVASI AIR
}

\section{SIMULATION OF TRENCHES PLACEMENT AS A MEAN OF WATER CONSERVATION OPTIMIZATION}

\author{
Akhmadi Puguh Raharjo \\ Perekayasa pada Pusat Teknologi Reduksi Risiko Bencana (PTRRB) - BPPT. \\ Gedung 820 Lantai 1, Komplek Perkantoran PUSPIPTEK, Tangerang Selatan, Banten 15314. \\ e-mail: akhmadi.puguh@bppt.go.id
}

\begin{abstract}
Trenching is a form of soil and water conservation engineering that is commonly used and is known to be effective in controlling runoff and increasing water content in the root zone of plants. There are various configurations of trench placement in the field and this study aims to simulate the placement of trench by comparing the three trench configurations to find out which configuration is most effective in capturing surface runoff. The simulation is carried out by calculating the catchment capacity of surface runoff under different rainfall intensity conditions and runoff coefficients in the three trench configurations that have different catchment areas. From the calculation, it is known that configuration 3 in optimal conditions has a comparative advantage of $41.67 \%$ - $68.80 \%$ (compared to configuration 1) and $27.78 \%$ - $52.83 \%$ (compared to configuration 2). Meanwhile, configuration 2 has a comparative advantage of $13.89 \%-16.06 \%$ when compared to configuration 1. From the calculation it is also known that there are conditions where the three configurations will produce a uniform value so that there will be no comparative advantage between the three configurations. This condition is generally above the rain intensity of $50 \mathrm{~mm}$ per hour and the runoff coefficient is above 0.45 .
\end{abstract}

Keywords: trench configuration, soil and water conservation, rainwater harvesting, runoff reduction, water conservation optimization.

\begin{abstract}
ABSTRAK
Pembuatan rorak atau parit buntu merupakan salah satu bentuk konservasi tanah dan air yang umum digunakan dan diketahui efektif dalam mengendalikan limpasan permukaan dan meningkatkan kadar air di zona perakaran tanaman. Terdapat beragam konfigurasi penempatan rorak di lapangan dan kajian ini bertujuan untuk melakukan simulasi penempatan rorak dengan membandingkan tiga konfigurasi rorak untuk mengetahui konfigurasi yang paling efektif dalam menangkap limpasan permukaan. Simulasi dilakukan dengan melakukan perhitungan kapasitas penangkapan limpasan permukaan pada kondisi intensitas curah hujan dan koefisien limpasan permukaan yang berbeda pada ketiga konfigurasi rorak yang memiliki luas area tangkapan yang berbeda. Dari hasil perhitungan diketahui bahwa konfigurasi 3 pada kondisi optimal memiliki keunggulan komparatif 41,67\% - 68,80\% (terhadap konfigurasi 1) dan 27,78\% - 52,83\% (terhadap konfigurasi 2). Sementara itu konfigurasi 2 memiliki keunggulan komparatif sebesar 13,89\% - 16,06\% bila dibandingkan dengan konfigurasi 1. Dari perhitungan juga diketahui bahwa terdapat kondisi dimana ketiga konfigurasi akan menghasilkan nilai yang seragam sehingga tidak ada keunggulan komparatif diantara ketiga konfigurasi tersebut. Kondisi ini umumnya berada di atas intensitas hujan $50 \mathrm{~mm} / \mathrm{jam}$ dan koefisien limpasan permukaan di atas 0,45.
\end{abstract}

Kata kunci: konfigurasi rorak, konservasi tanah dan air, pemanenan air hujan, pengurangan limpasan permukaan, pengoptimalan konservasi air.

\subsection{Latar Belakang}

Definisi pemanenan air hujan menurut Brown et al. (2005) adalah proses menangkap, mengalihkan dan menyimpan air hujan untuk keperluan lain seperti irigasi halaman, konsumsi domestik, pengisian akuifer maupun untuk pengurangan limpasan 
permukaan. Untuk kawasan perkotaan, bentuk pemanenan air yang paling umum digunakan adalah sumur resapan. Namun sistem penampungan menggunakan drum, gentong ataupun tanki air dapat menjadi alternatif untuk lahan di kawasan perkotaan yang memiliki luas terbatas (Raharjo, 2019).

Pengertian konservasi tanah dan air Berdasarkan Pasal 1 Undang-Undang Republik Indonesia Nomor 37 Tahun 2014 adalah upaya perlindungan, pemulihan, peningkatan dan pemeliharaan fungsi tanah pada lahan sesuai dengan kemampuan dan peruntukan lahan untuk mendukung pembangunan yang berkelanjutan dan kehidupan yang lestari (Republik Indonesia, 2014). Dalam Undang-Undang tersebut, yakni dalam pasal 3, disebutkan bahwa tujuan dari penyelenggaraan konservasi tanah dan air adalah untuk melindungi permukaan tanah dari pukulan air hujan yang jatuh, meningkatkan kapasitas infiltrasi tanah dan mencegah terjadinya konsentrasi limpasan permukaan. Lebih lanjut, dalam pasal 13 ayat 2 dicantumkan bahwa konservasi tanah dan air diselenggarakan dengan metode vegetatif, agronomi, sipil teknis (pembuatan bangunan konservasi tanah dan air), manajemen dan metode lain yang sesuai dengan perkembangan ilmu pengetahuan dan teknologi.

Salah satu bentuk bangunan konservasi tanah dan air yang umum digunakan di luar kawasan urban adalah rorak atau parit buntu. Teknik pemanenan air hujan menggunakan saluran peresapan dan rorak diketahui efektif dalam mengendalikan limpasan permukaan dan meningkatkan kadar air di zona perakaran tanaman (Surdianto, 2012). Rorak juga mampu mengurangi limpasan permukaan sebesar $88 \%$ (Noeralam et al., 2003) maupun hingga $94 \%$ apabila dikombinasikan dengan mulsa vertikal (Noeralam, 2002) bila dibandingkan dengan lahan terbuka tanpa perlakuan.

Dari penelusuran literatur diketahui terdapat berbagai macam dimensi rorak yang menunjukkan tidak adanya pedoman pasti di lapangan. Sebagai contoh ada rorak yang berukuran 4-5 meter $\times 0,5$ meter dengan kedalaman $60 \mathrm{~cm}$ (Arsyad, 2010). Ada pula yang berukuran $2 \times 0,4$ meter dengan kedalaman $40 \mathrm{~cm}$ (Noeralam et al., 2003).

Hipotesis awal yang melatarbelakangi kajian ini adalah adanya perbedaan tingkat penangkapan air pada konfigurasi rorak yang berbeda meskipun memiliki jumlah rorak yang sama dan menempati unit lahan dengan luas yang sama, seperti disajikan pada Gambar 1 . Arah kelerengan pada gambar tersebut adalah dari puncak atas gambar menuju ke dasar bawah gambar.

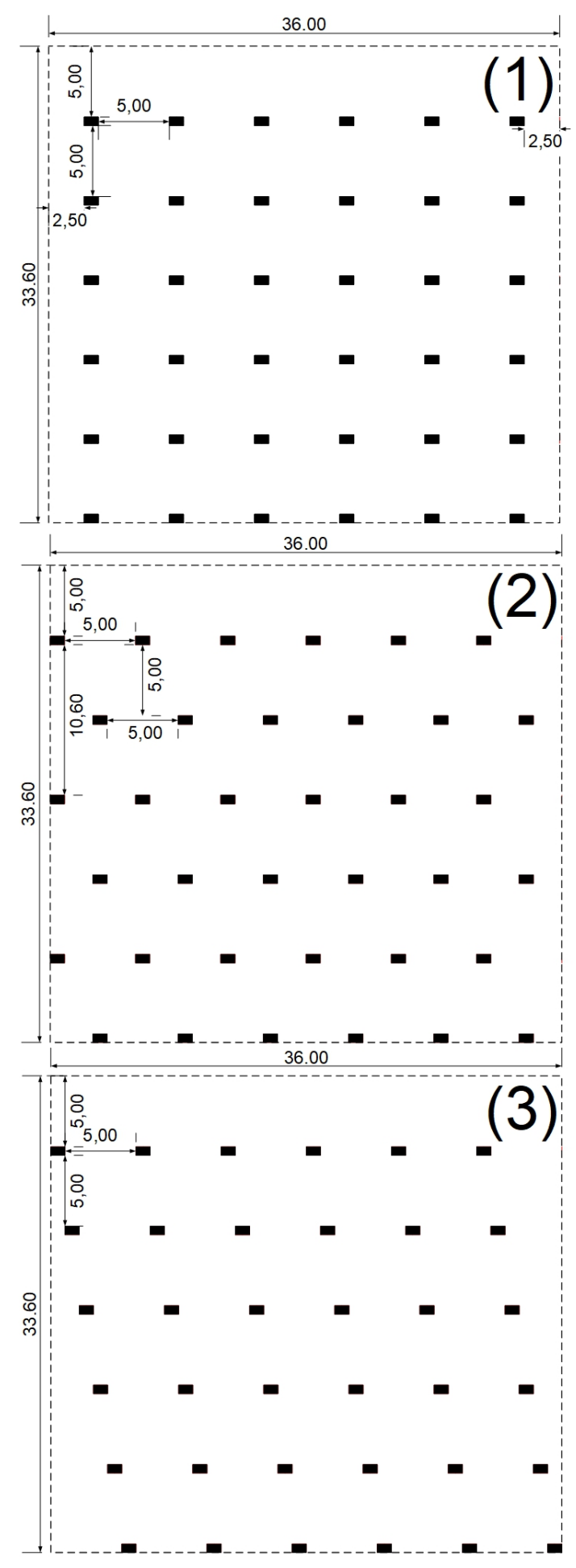

Gambar 1. Tiga Konfigurasi Rorak yang Berbeda pada Unit Luasan yang Sama. Rorak, Disimbolkan dengan Kotak Hitam, Memiliki Luas 1 x 0,6 meter dengan Kedalaman 0,5 meter (Luas 0,6 $\mathrm{m}^{2}$ dan Volume $0,3 \mathrm{~m}^{3}$ ) 
Dimensi rorak pada Gambar 1 mengacu pada penelitian Fachruddin et al. (2015) namun dengan perubahan pada lebar dan kedalaman rorak. Pada Gambar 2 disajikan ilustrasi area tangkapan pada ketiga konfigurasi rorak (warna hijau), dimana area penangkapan konfigurasi 1 nampak lebih kecil dari konfigurasi 2, dan area penangkapan konfigurasi 2 nampak lebih kecil dari konfigurasi 3 .

Kajian ini dimaksudkan mensimulasikan kondisi intensitas curah hujan $(\mathrm{CH})$ tertentu pada lahan dengan nilai koefisien limpasan permukaan (C) tertentu pada ketiga konfigurasi rorak yang dikaji untuk melihat seberapa jauh perbedaan antara ketiga konfigurasi rorak tersebut. Kajian ini diharapkan mampu menjadi semacam panduan kasar di lapangan dalam mengoptimalkan konservasi tanah dan air.

\subsection{Tujuan Penelitian}

Tujuan kajian ini adalah untuk melakukan simulasi penempatan rorak pada kondisi curah hujan dan koefisien limpasan permukaan tertentu. Hasil kajian ini diharapkan dapat menjadi panduan awal dalam pengoptimalan konservasi air dan tanah.

\section{METODOLOGI PENELITIAN}

\subsection{Bahan}

Objek utama yang menjadi bahan dalam kajian ini adalah ketiga konfigurasi rorak yang berbeda yang akan menjadi objek simulasi perhitungan. Alat yang dibutuhkan dalam kajian ini adalah seperangkat komputer yang mampu melakukan komputasi numerik dan memiliki akses internet.

\subsection{Metode}

\subsubsection{Waktu dan Lokasi Penelitian}

Kajian ini dilakukan dari bulan Januari hingga Maret 2020. Kaidah yang digunakan adalah kaidah desktop study.

\subsubsection{Metode Pengumpulan Data}

Dalam kajian ini tidak ada data yang dikumpulkan sebagai dasar simulasi konfigurasi rorak. Nilai intensitas curah hujan dan koefisien limpasan permukaan (C) yang digunakan merupakan nilai yang dipilih secara bebas dan tidak mencerminkan kondisi spesifik di suatu wilayah, namun sengaja dipilih berjenjang dengan interval seragam.
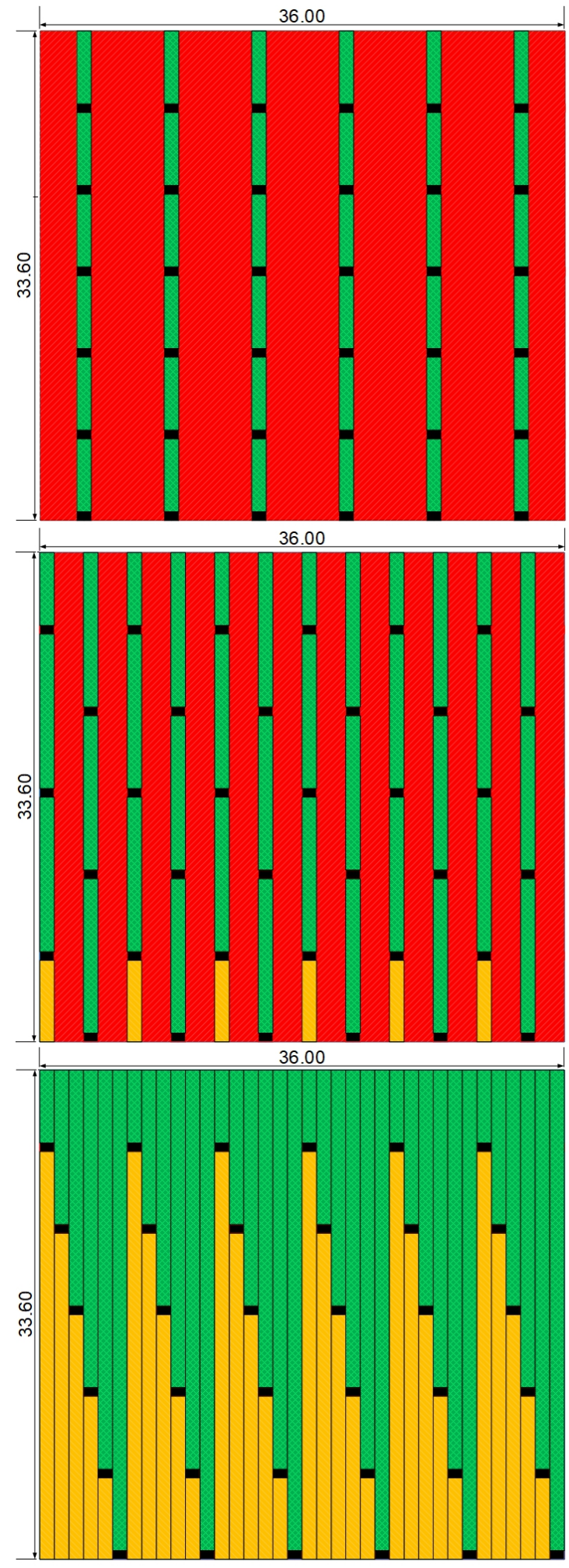

Gambar 2. Warna Hijau Menunjukkan Area yang Ditangkap oleh Rorak, Warna Merah Menunjukkan Area yang Tidak Ditangkap oleh Rorak dan Warna Kuning Menunjukkan

Area yang Akan Ditangkap oleh Rorak

Apabila Unit Lahan Diperluas atau

Diperpanjang ke Arah Bawah Mengikuti Arah Lereng. 
Tabel 1. Jumlah Rorak dan Persentase Area yang Ditangkap oleh Rorak pada Ketiga Konfigurasi

\begin{tabular}{|cccc}
\hline \multicolumn{1}{c}{ Karakteristik } & Konfigurasi 1 & Konfigurasi 2 & Konfigurasi 3 \\
\hline Jumlah rorak total per 33,6 x 36 meter (referensi) & 36 & 36 & 36 \\
\hline Luas permukaan rorak total per unit referensi $\left(\mathrm{m}^{2}\right)$ & 21,6 & 21,6 & 21,6 \\
Persentase (\%) & $\mathbf{( 1 , 7 9 )}$ & $\mathbf{( 1 , 7 9 )}$ & $\mathbf{( 1 , 7 9 )}$ \\
\hline Luas area yang ditangkap oleh rorak per ref $\left(\mathrm{m}^{2}\right)$ & 201,6 & 369,6 & $\mathbf{7 0 5 , 6}$ \\
\hline Persentase (\%) & $\mathbf{( 1 6 , 6 7 )}$ & $\mathbf{( 3 0 , 5 6 )}$ & $\mathbf{( 5 8 , 3 3 )}$ \\
\hline Luas area tidak tertangkap oleh rorak per ref $\left(\mathrm{m}^{2}\right)$ & 1.008 & 840 & $\mathbf{( 4 1 . 6 7 )}$ \\
\hline Persentase (\%) & $\mathbf{( 8 3 , 3 3 )}$ & $\mathbf{( 6 9 , 4 4 )}$ & $\mathbf{1 9 , 6 0}$ \\
\hline Rata-rata area yang ditangkap per rorak $\left(\mathrm{m}^{2}\right)$ & 5,60 & 10,27 & $\mathbf{3 0 0}$ \\
\hline Jumlah rorak total per 1 Ha & 306 & 306 & $\mathbf{1 8 0}$ \\
\hline Luas permukaan rorak total per Ha $\left(\mathrm{m}^{2}\right)$ & 183,6 & $\mathbf{( 1 , 7 9 )}$ \\
\hline Persentase (\%) & $\mathbf{( 1 , 8 2 )}$ & $\mathbf{( 1 , 8 2 )}$ & $8.657,6$ \\
\hline Luas area yang ditangkap oleh rorak per Ha $\left(\mathrm{m}^{2}\right)$ & $1.713,6$ & 3.332 & $\mathbf{( 8 5 , 8 9 )}$ \\
\hline Persentase (\%) & $\mathbf{( 1 7 , 0 0 )}$ & $\mathbf{( 3 3 , 0 6 )}$ & $1.422,4$ \\
\hline Luas area tidak tertangkap oleh rorak per Ha $\left(\mathrm{m}^{2}\right)$ & $8.366,4$ & 6.748 & $\mathbf{( 1 4 , 1 1 )}$ \\
\hline Persentase (\%) & $\mathbf{( 8 3 , 0 0 )}$ & $\mathbf{( 6 6 , 9 4 )}$ & $\mathbf{2 8 , 8 6}$ \\
\hline Rata-rata area yang ditangkap per rorak $\left(\mathrm{m}^{2}\right)$ & 5,60 & 10,89 & \\
\hline Sumber: & & & \\
\hline
\end{tabular}

Sumber: Hasil Perhitungan (2020)

\subsubsection{Metode Analisis Data}

Langkah-langkah analisis data yang dilakukan untuk bagian pertama meliputi:

- Menghitung debit rancangan total menggunakan rumus metode Rasional sebagai berikut (Chow et al., 1988):

$$
Q_{T}=0,00278 C I_{t c, T} A
$$

dimana:

$Q_{T}=$ Debit puncak ( $\mathrm{m}^{3} /$ detik) untuk periode ulang $T$ tahun;

$C=$ Koefisien limpasan permukaan (run off), yang dipengaruhi kondisi tata guna lahan pada daerah tangkapan air (DAS). Nilai $C$ yang digunakan adalah 0,1 hingga 0,95 ;

$I_{t c_{n}, T}=$ Intensitas hujan rata-rata (mm/jam) untuk waktu konsentrasi (tc) dan kala ulang $T$ tahun. Nilai I yang digunakan adalah $10-120 \mathrm{~mm} / \mathrm{jam}$; dan

$A=$ Luas daerah tangkapan air/DAS (Ha). Luas area yang digunakan adalah unit referensi $(33,6 \times 36$ $\mathrm{m}$, atau $0,1210 \mathrm{Ha}$ ) ataupun luas 1 hektar, seperti yang disajikan oleh Tabel 1
- Menghitung persentase pengurangan limpasan permukaan dengan mengurangi nilai debit rencana total dengan total kapasitas penampungan rorak untuk unit referensi maupun untuk luasan 1 hektar.

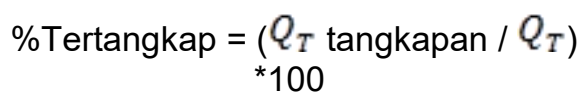

$Q_{T}$ tangkapan didapatkan dengan menggunakan luas area yang ditangkap oleh rorak per unit referensi atau per satuan hektar (Tabel 1, baris $4 \& 12$ ).

- Menghitung nilai koreksi terhadap persentase pengurangan limpasan permukaan dengan menggunakan persamaan:

Koreksi $=\underset{\text { tangkapan }) / 3600}{\left(\text { Kapasitas rorak total } / Q_{T}\right.}$

Kapasitas rorak total di sini adalah hasil perkalian antara jumlah total rorak dengan kapasitas per rorak dalam $\mathrm{m}^{3}$. Jika nilai koreksi $\geq 1$, maka \%Tertangkap cukup dikalikan dengan 1. Namun jika nilai koreksi $<1$, maka \%Tertangkap harus dikalikan nilai tersebut. 
- Melakukan tabulasi hasil perhitungan dalam bentuk tabel.

\section{HASIL DAN PEMBAHASAN}

\subsection{Hasil}

\subsubsection{Persentase Pengurangan Limpasan} Permukaan untuk Ketiga Konfigurasi Hasil perhitungan persentase pengurangan limpasan permukaan pada intensitas $\mathrm{CH}$ dan nilai koefisien $\mathrm{C}$ tertentu untuk setiap ketiga konfigurasi disajikan pada Tabel 2 hingga Tabel 4. Warna jingga pada ketiga tabel tersebut menunjukkan nilai persentase pengurangan limpasan permukaan yang sama untuk ketiga konfigurasi rorak. Kemudian, warna kuning menunjukkan nilai persentase pengurangan limpasan permukaan yang sama antara konfigurasi 3 dengan konfigurasi 2 . Sementara itu warna biru menunjukkan nilai persentase pengurangan limpasan permukaan yang lebih tinggi pada suatu konfigurasi dibanding dengan konfigurasi sebelumnya (konfigurasi $3>$ konfigurasi 2, dan konfigurasi $2>$ konfigurasi 1 ).

Tabel 2. Persentase Pengurangan Limpasan Permukaan untuk Konfigurasi 1

\begin{tabular}{|c|c|c|c|c|c|c|c|c|c|c|c|c|c|c|c|c|c|c|c|c|c|c|c|c|c|}
\hline \multirow[t]{2}{*}{ C } & \multicolumn{12}{|c|}{$\begin{array}{l}\text { Persentase pengurangan aliran permukaan (\%) pada intensitas } \mathrm{CH} \text { tertentu } \\
\text { (mm/jam) - Konfigurasi } 1 \text { (per unit referensi) }\end{array}$} & \multirow[t]{2}{*}{ C } & \multicolumn{12}{|c|}{$\begin{array}{l}\text { Persentase pengurangan aliran permukaan (\%) pada intensitas } \mathrm{CH} \text { tertentu } \\
(\mathrm{mm} / \mathrm{jam}) \text { - Konfigurasi } 1 \text { (per hektar) }\end{array}$} \\
\hline & 10 & 20 & 30 & 40 & 50 & 60 & 70 & 80 & 90 & 100 & 110 & 120 & & 10 & 20 & 30 & 40 & 50 & 60 & 70 & 80 & 90 & 100 & 110 & 120 \\
\hline 0,10 & 677 & 16,67 & 16,67 & 16,67 & 16,67 & 16,67 & 16,67 & 16,67 & 16,67 & 16,67 & 16,67 & 16 & 0,10 & 17,00 & 17,00 & 17,00 & 17,00 & 17,00 & 17,00 & 17,00 & 17,00 & 17,00 & 017,00 & 17,00 & 17,00 \\
\hline ,15 & & $16,6 \%$ & 16,67 & 16,67 & 16,67 & 16,67 & 16,67 & 16,67 & 16,67 & 16,67 & 16,67 & 16,6 & 0,15 & & 17,00 & 17,00 & 17,00 & 17,0 & 17,00 & 17,00 & 17,0 & $1,1,0$ & $m, 0$ & 17,00 & 17,00 \\
\hline, 20 & 67 & 1 & 16 & 16,67 & 16,67 & 16,67 & 16,67 & 16,67 & 16,67 & 16,67 & 16,67 & 16,6 & 0,20 & & 17,00 & 17,00 & 17,00 & 17,00 & 17,00 & 17,00 & 17 & $\pi, 0$ & 01,6 & 17,00 & 17,00 \\
\hline 25 & 67 & 7 & 16, & 16,67 & 16,67 & 16,67 & 16,67 & 16,67 & 16,67 & 16,67 & 16,67 & 16,6 & 0,25 & & 17,00 & 17,00 & 17,00 & 17,0 & 17,00 & 17,00 & 17 & 17,00 & 077,0 & 17,00 & 17,00 \\
\hline 30 & 67 & 1 & 16 & 16 , & 16,67 & 16,67 & 16 , & 16,67 & 16,67 & 16,67 & 16,67 & 16 & 0,30 & & 17,00 & 17,00 & 17,00 & 17 & 17,00 & 17,00 & & & 00 & 17,00 & 17,00 \\
\hline 0,35 & 67 & 1 & 16 & 16, & 16,67 & 16,67 & 16 . & 16,67 & 16,67 & 16,67 & 16,67 & 16,6 & 0,35 & & 17,00 & 17,00 & 17 & 17 & 17,00 & 17,00 & & & 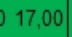 & 17,00 & 17,00 \\
\hline 0,40 & 67 & 1 & 16 & 16,6 & 16,67 & 16,67 & 16 , & 16,67 & 16,67 & 16,67 & 16,67 & 16,6 & 0,40 & & 17,00 & 17,00 & 17 & 17,00 & 17,00 & 17,00 & & & $\pi, 00$ & 17,00 & 17,00 \\
\hline 45 & 67 & 7 & 16 & 16, & 16,67 & 16,67 & 16 & 7 & 16 & 16 & 16,67 & 16,53 & 0,45 & & 17,00 & 17,00 & & 17 & 17,00 & 1 & & & . & 17,00 & 16,86 \\
\hline 50 & 67 & 16,67 & 16 & 16,67 & 16,67 & 16,67 & 16 & 16,67 & 16,67 & 16,67 & 16,23 & 14,88 & 0,50 & 00 & 17,00 & 017 & 1 & 17 & 17,00 & & & & & 16,56 & 15,18 \\
\hline 55 & 67 & 16 , & 1 & 10 & 16,67 & 16, & 16 & 67 & 16 & 16,23 & 14,76 & 13,53 & 0,55 & & 17,0 & 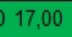 & & 8 & 17 & & & & 56 & \begin{tabular}{|l|l|}
5,05 \\
\end{tabular} & 13,80 \\
\hline 60 & 67 & 16,67 & 16 & 16,67 & 16,67 & 16,67 & 0 & 6,67 & 16,53 & 14,88 & 13,53 & 12,40 & 0,60 & & 17,0 & II & 17 & 11 & 17,00 & 17 & 17 & 176 & 615,18 & 13 & 12 \\
\hline 0,65 & 67 & 16,67 & 16,6 & 16,67 & 16,67 & 16,67 & 16 . & 16,67 & 15,26 & 13,74 & 12,49 & 11,45 & 0,65 & & 17,00 & 17,00 & 17 & 17 & 17,00 & 17,00 & 17 & 10,5 & 714,01 & 12,74 & 11,67 \\
\hline 0 & 67 & 16,67 & 16,67 & 16,67 & 16,67 & 16,67 & 16,67 & 15,94 & 14 & 12,75 & 11,59 & 10,63 & 0,70 & 00 & 17,00 & 017,00 & ) 17 & 17,00 & 17,00 & 17,00 & 16,26 & 14,44 & 5 13,01 & 11,83 & 310,84 \\
\hline 5 & 67 & 16,67 & 16,67 & 16,67 & 16,67 & 16,67 & 16,67 & 14,88 & 13,23 & 11,90 & 10,82 & 9,92 & 0,75 &, 00 & 17,00 & 017,00 & 17,00 & 17,0 & 17,00 & 17,00 & 15,18 & 13,49 & 912,14 & 41,04 & 10,12 \\
\hline 30 & \begin{tabular}{|l|l|}
67 \\
\end{tabular} & 16,67 & 16,67 & 16,67 & 16,67 & 16,67 & 15,94 & 13,95 & 12,40 & 11,16 & 10,15 & 9,30 & 0,80 &, 00 & 17,00 & 017,00 & 17,00 & 17 & 17,00 & 16,26 & 1 & 12,65 & 511,3 & \begin{tabular}{|l|l|} 
& 10,35 \\
\end{tabular} & 9,49 \\
\hline 35 & 67 & 16,67 & 16,67 & 16,67 & 16,67 & 16,67 & $15, \mathrm{C}$ & 13,13 & 11,67 & 10,50 & 9,55 & 8,75 & 0,85 &, 00 & 17,00 & 017,00 & 17,00 & 17 & 17,00 & 15,30 & 13 & 11,90 & 0 10,71 & 74 & 8,93 \\
\hline 0 & 3,67 & 16,67 & 16,67 & 16,67 & 16,67 & 16,53 & 14, & 12,40 & 11,02 & 9,92 & 9,02 & 8,27 & 0,90 &, 0 & 17,00 & 017,00 & 17,00 & & 16,86 & 14,45 & & 11,24 & 410,12 & 9,20 & 8,43 \\
\hline 0,95 & 5,67 & 16,67 & 16,67 & 16,67 & 16,67 & 15,66 & 13,43 & 11,75 & 10,44 & 9,40 & 8,54 & 7,83 & 0,95 & & 17,00 & $0 \quad 17,00$ & & & 15,98 & 13,69 & & 10,65 & \begin{tabular}{|cc}
5 & 9,59
\end{tabular} & 8,71 & 7,99 \\
\hline
\end{tabular}

Sumber: Hasil Perhitungan (2020)

Tabel 3. Persentase Pengurangan Limpasan Permukaan untuk Konfigurasi 2

\begin{tabular}{|c|c|c|c|c|c|c|c|c|c|c|c|c|c|c|c|c|c|c|c|c|c|c|c|c|c|}
\hline \multirow[t]{2}{*}{ C } & \multicolumn{12}{|c|}{$\begin{array}{l}\text { Persentase pengurangan aliran permukaan (\%) pada intensitas } \mathrm{CH} \text { tertentu } \\
(\mathrm{mm} / \mathrm{jam}) \text { - Konfigurasi } 2 \text { (per unit referensi) }\end{array}$} & & \multicolumn{12}{|c|}{$\begin{array}{l}\text { Persentase pengurangan aliran permukaan (\%) pada intensitas } \mathrm{CH} \text { tertentu } \\
\text { (mm/jam) - Konfigurasi } 2 \text { (per hektar) }\end{array}$} \\
\hline & 10 & 20 & 30 & 40 & 50 & 60 & 70 & 80 & 90 & 100 & 110 & 120 & & 10 & 20 & 30 & 40 & 50 & 60 & 70 & 80 & 90 & 100 & 110 & 120 \\
\hline 10 & & 30,56 & 630,56 & 30,56 & 30,56 & 30,56 & 30,56 & 30,56 & 30,56 & 30,56 & 30,56 & 3 & 0,10 & & 33,06 & 633,06 & 33,06 & 633,06 & \begin{tabular}{l|l}
6 & 33,06
\end{tabular} & 633,06 & 633,06 & 633,06 & 6333,06 & 33,06 & 63 \\
\hline 15 & & 30,56 & 630,56 & 30,56 & 30,56 & 30,56 & 30,56 & 30,56 & 30,56 & 31 & 66 & 30,56 & 0,15 & & 06 & 633,06 & 33,06 & 633,06 & 33,06 & 633,0 & 33,06 & 633,06 & 33 & & 33,0 \\
\hline 0,20 & & 30,56 & 630,56 & 30,56 & 30,56 & 30,56 & 30,56 & 30,56 & 30,56 & 30 & 56 & 30 & 20 & & 06 & 633,06 & 33,06 & 633,06 & 33,06 & 633,06 & 633,06 & 6 33,06 & 633,0 & & o \\
\hline 25 & & 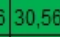 & 630,56 & 30,56 & 30,56 & 30,56 & 30,56 & 30,56 & 30,56 & 30 & 56 & 29 & 25 & & 06 & 633,06 & 33,06 & 633,06 & \begin{tabular}{l|l}
63,06 \\
\end{tabular} & 633,06 & 633,06 & 633,06 & 633 & & 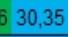 \\
\hline 0, & & 30,56 & 630,56 & 30 & 30,5 & 30,56 & 30 & 30 & & 25 & 5 & 24 & 0,30 & & 66 & 633,06 & 33 & 3,06 & $6[33,06$ & 633,06 & 633,06 & 633,06 & . & & , \\
\hline 35 & & 630,56 & 630,56 & 30, & 30,56 & 30,56 & 30,56 & 30 & 28 & 25 & & 21 & 0,35 & & 16 & 633,06 & 33,06 & 633,06 & $6 \mid 33,06$ & 633,06 & 632,52 & 228,91 & 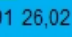 & & 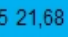 \\
\hline 0,40 & & 630,56 & 630,56 & 30,56 & 30,56 & 30,56 & 30,56 & 27 & 24 & 22,32 & 20,29 & 18 & 0,40 & & 06 & 633,06 & 33,06 & 633,06 & \begin{tabular}{l|l}
6 & 33,06
\end{tabular} & 632,52 & 228,46 & 625,30 & 3022,77 & & (18, \\
\hline 45 & & 30,56 & 630,56 & 30 & 30,56 & 30,56 & 28 & 24 & $2 ?$ & 19,84 & 04 & 16 & 45 & & 16 & 633,06 & 33 & 633,06 & \begin{tabular}{l|l}
63,06 \\
\end{tabular} & 62 & 0 & & 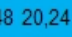 & $0,4 v$ & 016,8 \\
\hline & & 30.56 & 630 & 30 & 30, & 29,76 & 25 & 22 & 19 & 17 & 16,23 & 14 & 0,50 & & 6 & 633 & 3 & 633,06 & \begin{tabular}{l|l}
6 & 30,35 \\
\end{tabular} & & & & 418 & 16,56 & 615 \\
\hline & & 30,56 & se & 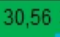 &, 56 & 27, & 2 & 20 & & 16 & & 13 & 0,55 & & 33,06 & 63 & 3 & 年, & \begin{tabular}{l|l}
627, \\
\end{tabular} & & & & & & T \\
\hline & & . & 630 & 30, & 29,76 & 24,80 & 21,2 & 18,60 & 16 & 14 & 13 & 12 & 60 & & 33 & 633 & 33 & 630,35 & \begin{tabular}{l|l|l}
5 & 25,30
\end{tabular} & 2 & 878,9 & 716,86 & 367 & & 0 \\
\hline & & 30, & 630,5 & 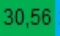 & 27,47 & 22,89 & 19,6 & 17,17 & 15 & 13 & & 11 & 0, & & & 633 & 33 & 628,02 & \begin{tabular}{l|l|l}
2 & 23,35
\end{tabular} & & 117,51 & 11 & $8 t$ & & $\begin{array}{l}4.11, \\
\end{array}$ \\
\hline & & , & 630,5 & 30,56 & 25,51 & 21,26 & 18,22 & 15 & 14 & 12 & 9 & 10 & 0,70 & & 6 & 6 33,06 & $3:$ & 226,02 & \begin{tabular}{l|l|l|}
2 & 21,68
\end{tabular} & 818,58 & 816,26 & 61 & 50 & 1 & 3 10, \\
\hline 0,75 & & 30,56 & 630,56 & 29,76 & 23,81 & 19,84 & 17,01 & 14,88 & 13,23 & 11, & 82 & 2 & 0,75 & & 33,06 & 633,06 & 30 & 524,28 & \begin{tabular}{l|l|l|}
8 & 20,24 \\
\end{tabular} & 417,35 & 515,18 & 813,49 & 1912,14 & $4 \mid 11,04$ & 410, \\
\hline 0,80 & & 30,5 & 630,56 & 27,90 & 22,32 & 18,60 & 15,94 & 13,95 & 12 & 11 & 10,15 & 0 & 0,80 & & & 633 & 328 & 622,77 & \begin{tabular}{l|l|l}
7 & 18,97
\end{tabular} & 716,26 & 2614,23 & 31 & 35 & 10,35 & 49 \\
\hline 0,85 & & 30,4 & 630,56 & 26,26 & 21,01 & 17,51 & 15,00 & 13,13 & 11,67 & 10 & s & 6 & s & & 66 & 633,06 & 26,78 & 821,43 & $\begin{array}{ll}3 & 17,86 \\
\end{array}$ & 615,30 & $\begin{array}{lll}0 & 13,39\end{array}$ & 911,90 & 010,71 & 9,74 & 93 \\
\hline 0,90 & 56 & 30,4 & 630,56 & 24,80 & 19,84 & 16,53 & 14 & 12,40 & 11,02 & 9,9 & 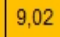 & 8,27 & 0,90 & & 33,06 & 633,06 & 25,30 & 020,24 & \begin{tabular}{l|l|l}
4 & 16,86
\end{tabular} & 614,45 & 512,65 & 511,24 & 2410,12 & $\begin{array}{ll}2 & 9,20\end{array}$ & \\
\hline 95 & & 30,5 & 630,56 & 23,49 & 18,80 & 15,66 & 13,43 & 11,75 & 10,44 & 9,40 & 8 & 7 & 0 & & 33,06 & 631,95 & 23 & $\begin{array}{l}6 \\
\end{array}$ & \begin{tabular}{l|l|l|}
75,98 \\
\end{tabular} & 813,69 & 911,98 & 810,65 & $5 \quad 9,59$ & 8,71 & 95 \\
\hline
\end{tabular}

Sumber: Hasil Perhitungan (2020)

Tabel 4. Persentase Pengurangan Limpasan Permukaan untuk Konfigurasi 3 


\begin{tabular}{|c|c|c|c|c|c|c|c|c|c|c|c|c|c|c|c|c|c|c|c|c|c|c|c|c|c|}
\hline & \multicolumn{12}{|c|}{$\begin{array}{l}\text { Persentase pengurangan aliran permukaan (\%) pada intensitas } \mathrm{CH} \text { tertentu } \\
\text { (mm/jam) - Konfigurasi } 3 \text { (per unit referensi) }\end{array}$} & & \multicolumn{12}{|c|}{$\begin{array}{l}\text { Persentase pengurangan aliran permukaan (\%) pada intensitas } \mathrm{CH} \text { tertentu } \\
(\mathrm{mm} / \mathrm{jam}) \text { - Konfigurasi } 3 \text { (per hektar) }\end{array}$} \\
\hline & 10 & 20 & 30 & 40 & 50 & 60 & 70 & 80 & 90 & 100 & 110 & $\overline{120}$ & & 10 & 20 & 30 & 40 & 50 & 60 & 70 & 80 & 90 & 100 & 110 & 120 \\
\hline 10 & 33 & 58,33 & 58,33 & 58,33 & 58,33 & 58,33 & 58,33 & 58,33 & 58,33 & 58,33 & 58,33 & 58,3 & 0,10 & & \begin{tabular}{|l|l|}
85,89 \\
\end{tabular} & 85,89 & 85,89 & 85,89 & 85,89 & 85,898 & 85,89 & 85,89 & 85,89 & 82,79 & 75,89 \\
\hline 15 & & 58,33 & 58,33 & 58,33 & 58,33 & 58,33 & 58,33 & 58,33 & 58,33 & 58 & 54,11 & 49,6 & 15 & & 9 & 85 & 85,89 & 85,89 & 85,89 & 97 & 75,89 & & 60,71 & & 50,59 \\
\hline 20 & & 3 & 58,33 & 58,33 & 58 & 58,33 & 58,33 & 55,80 & 49,60 & 44,64 & 40,58 & 37 & 0,20 & & & 8 & 85,89 & 85,89 & 75,89 & 65,055 & & & 3 & & \\
\hline 5 & & & 58 & & 58 & 3 & & & & & & 29,76 & 0,25 & & & & 9 & & & & & & & & 35 \\
\hline 30 & & & & & 58 & & & & & & & & & & & & & & & & & & & & \\
\hline 35 & & & & & 51 & & & & & & & & & & & & & & & & & & & & \\
\hline 40 & & & & & & & & & & & & & 0 & & & & & & & & & & & & \\
\hline 45 & & & 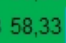 & & 39 & 33 & 28 & & & & & & 0,45 & & & & & & 33,73 & & 02 & & . & & \\
\hline 50 & & & 58 & 4 & 35,71 & 29,76 & & 22 & 19 & 17,86 & 3 & 14 & 0,50 & 89 & & & & 36,43 & 30,35 & 22 & $2 ?$ & 4 & 18 & 16 & \\
\hline 0,55 & & & 54 & 40,58 & 32,46 & 27. & & & 1 & 1 & & 13 & 0,55 & & 82, & & & 33,11 & 27 & & 2 & 0 & 1 & & \\
\hline 60 & & 58,33 & & & 29 & 24 & & & & & & &, 60 & & 18 & & & 30,35 & 25 & & & & & & \\
\hline & & 58 & & & & 22. & & & & & & & 0,65 & & 10 & & & & 2. & & & & & & \\
\hline & & & & & & 21,2 & & & & & & & 70 & & & & & & 2 & & & & & & \\
\hline 75 & 33 & 8,3 & 39 & 329,76 & 23,81 & 19,84 & 17 & 14 & 13,23 & 11 & 10,82 & 9 & 5 & 89 & 100 & $40 \quad$ & 30 & 24,28 & 20,24 & & 15 & 9 & 1 & 11,04 & 10 \\
\hline 0,80 & & 55,8 & 37 & 27 & 22 & 18,60 & & & 12 & 11 & 5 & & 30 & 89 & 56, & & & 77 & 18 & & & & & 35 & 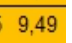 \\
\hline 0,85 & 33 & 52,52 & 35, & 126,26 & 21,01 & 17,51 & 15,00 & 13,13 & 11 & 10 & 55 & 5 & 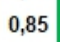 &, 89 & 53,57 & 35,71 & 26,78 & 21,43 & 17,86 & 301 & 13 & 11,90 & 11 & 4 & 93 \\
\hline 90 & 3 & 49,60 & 33, & 24,80 & 19,84 & 16,53 & 14 & 12,40 & 11,02 & 9, & 9,02 & 27 & 30 & & 50,59 & 33,73 & 25,30 & 20,24 & 16,86 & 51 & 12 & 11,24 & 10,12 & 20 & 43 \\
\hline 95 & 33 & 46,99 & 31,33 & 323,49 & 18,80 & 15,66 & 13,43 & 11,75 & 10,44 & 9,40 & 54 & 83 & 95 & & 47,93 & 31,95 & 23,96 & 19,17 & 15,98 & 13,691 & 11,98 & 10,65 & 9,59 & 8,71 & 7,99 \\
\hline
\end{tabular}

Sumber: Hasil Perhitungan (2020)

Warna hijau pada ketiga tabel tersebut menunjukkan kondisi optimal untuk setiap konfigurasi rorak tertentu. Pada konfigurasi rorak 1, nilai persentase pengurangan limpasan permukaan optimalnya adalah antara $16,67 \%$ hingga $17 \%$ dari kondisi tanpa rorak. Pada konfigurasi 2, nilai persentase pengurangan limpasan permukaan optimalnya adalah antara $30,56 \%$ hingga $33,06 \%$ dari kondisi tanpa rorak. Pada konfigurasi rorak 3 , nilai persentase pengurangan limpasan permukaan optimalnya adalah antara 58,33\% hingga $85,89 \%$ dari kondisi tanpa rorak

\subsection{Pembahasan \\ 3.2.1.Perbandingan antara Ketiga Konfigurasi}

Sebagaimana disajikan sebelumnya pada Gambar 2, kita dapat menduga secara sekilas dari gambar tersebut bahwa akan ada perbedaan kapasitas pengurangan limpasan permukaan dari ketiga konfigurasi rorak yang dikaji dalam kajian ini. Dari hasil perhitungan yang disajikan pada Tabel 2 hingga 4, ternyata terdapat kondisi curah hujan dan koefisien limpasan permukaan yang menghasilkan nilai yang sama untuk ketiga konfigurasi (dicirikan dengan warna jingga pada ketiga tabel tersebut).

Pada Tabel 5 di bawah disajikan kondisi intensitas $\mathrm{CH}$ dan koefisien limpasan permukaan yang menghasilkan nilai seragam untuk ketiga konfigurasi rorak. Pada bagian teratas nampak bahwa nilai intensitas curah hujan tertinggi yang menghasilkan nilai sama untuk ketiga konfigurasi rorak adalah 120 $\mathrm{mm} / \mathrm{jam}$ yakni pada kondisi koefisien limpasan permukaan sama dengan 0,45. Kemudian pada nilai intensitas hujan terendah yang menghasilkan nilai yang sama untuk ketiga konfigurasi rorak adalah 60 $\mathrm{mm} / \mathrm{jam}$ yakni pada kondisi koefisien limpasan permukaan sama dengan 0,90 sampai 0,95 .

Pada kondisi yang disajikan pada Tabel 5 tersebut tidak ada lagi pengaruhnya konfigurasi rorak mana yang kita pilih karena tetap akan menghasilkan nilai pengurangan limpasan permukaan yang sama. Namun demikian, nilai pengurangan limpasan permukaan yang sama pada ketiga konfigurasi rorak tersebut masih lebih baik daripada kondisi tanpa rorak yakni antara $7,83 \%$ hingga $7,99 \%$ (minimal) dan antara $16,53 \%$ hingga $16,86 \%$ (maksimal).

Tabel 5. Kondisi I dan C yang Menghasilkan Nilai Seragam untuk Ketiga Konfigurasi Rorak

\begin{tabular}{ccc}
\hline \multirow{2}{*}{ C } & \multicolumn{2}{c}{ Intensitas CH Seragam 3 Konfigurasi } \\
\cline { 2 - 3 } & Unit Referensi & Satuan Hektar \\
\hline 0,45 & $120 \mathrm{~mm} / \mathrm{jam}$ & $120 \mathrm{~mm} / \mathrm{jam}$ \\
0,50 & $110 \mathrm{~mm} / \mathrm{jam}$ & $110 \mathrm{~mm} / \mathrm{jam}$ \\
0,55 & $100 \mathrm{~mm} / \mathrm{jam}$ & $100 \mathrm{~mm} / \mathrm{jam}$ \\
0,60 & $90 \mathrm{~mm} / \mathrm{jam}$ & $90 \mathrm{~mm} / \mathrm{jam}$ \\
0,65 & $90 \mathrm{~mm} / \mathrm{jam}$ & $90 \mathrm{~mm} / \mathrm{jam}$ \\
0,70 & $80 \mathrm{~mm} / \mathrm{jam}$ & $80 \mathrm{~mm} / \mathrm{jam}$ \\
0,75 & $80 \mathrm{~mm} / \mathrm{jam}$ & $80 \mathrm{~mm} / \mathrm{jam}$ \\
0,80 & $70 \mathrm{~mm} / \mathrm{jam}$ & $70 \mathrm{~mm} / \mathrm{jam}$ \\
0,85 & $70 \mathrm{~mm} / \mathrm{jam}$ & $70 \mathrm{~mm} / \mathrm{jam}$ \\
0,90 & $60 \mathrm{~mm} / \mathrm{jam}$ & $60 \mathrm{~mm} / \mathrm{jam}$ \\
0,95 & $60 \mathrm{~mm} / \mathrm{jam}$ & $60 \mathrm{~mm} / \mathrm{jam}$ \\
\hline
\end{tabular}

Sumber: Hasil Perhitungan (2020) 
Pada Tabel 3 dapat dilihat kondisi intensitas $\mathrm{CH}$ dan koefisien limpasan permukaan yang menghasilkan nilai optimal untuk konfigurasi 2. Nilai intensitas curah hujan tertinggi yang menghasilkan nilai optimal untuk konfigurasi 2 adalah 120 $\mathrm{mm} / \mathrm{jam}$ yakni pada kondisi koefisien limpasan permukaan sama dengan 0,10 hingga 0,20 . Kemudian pada nilai intensitas hujan terendah yang menghasilkan nilai optimal untuk konfigurasi 2 adalah 30 $\mathrm{mm} / \mathrm{jam}$ yakni pada kondisi koefisien limpasan permukaan sama dengan 0,75 hingga 0,95 . Kondisi yang disajikan pada tabel tersebut merupakan panduan batas kondisi yang tidak boleh dilampaui apabila ingin mendapatkan nilai pengurangan limpasan permukaan yang optimal untuk konfigurasi 2.
Sementara itu pada Tabel 4 dapat dilihat kondisi intensitas $\mathrm{CH}$ dan koefisien limpasan permukaan yang menghasilkan nilai optimal untuk konfigurasi 3. Nilai intensitas curah hujan tertinggi yang menghasilkan nilai optimal untuk konfigurasi 3 adalah 100-120 $\mathrm{mm} / \mathrm{jam}$ yakni pada kondisi koefisien limpasan permukaan sama dengan 0,10. Kemudian pada nilai intensitas hujan terendah yang menghasilkan nilai optimal untuk konfigurasi 3 adalah $10 \mathrm{~mm} / \mathrm{jam}$ yakni pada kondisi koefisien limpasan permukaan sama dengan 0,80 hingga 0,95. Sebagaimana dinyatakan sebelumnya, nilai tersebut dapat pula dijadikan panduan untuk mendapatkan nilai pengurangan limpasan permukaan yang optimal untuk konfigurasi 3 .

Tabel 6. Selisih antara Konfigurasi 1 dan Konfigurasi 2

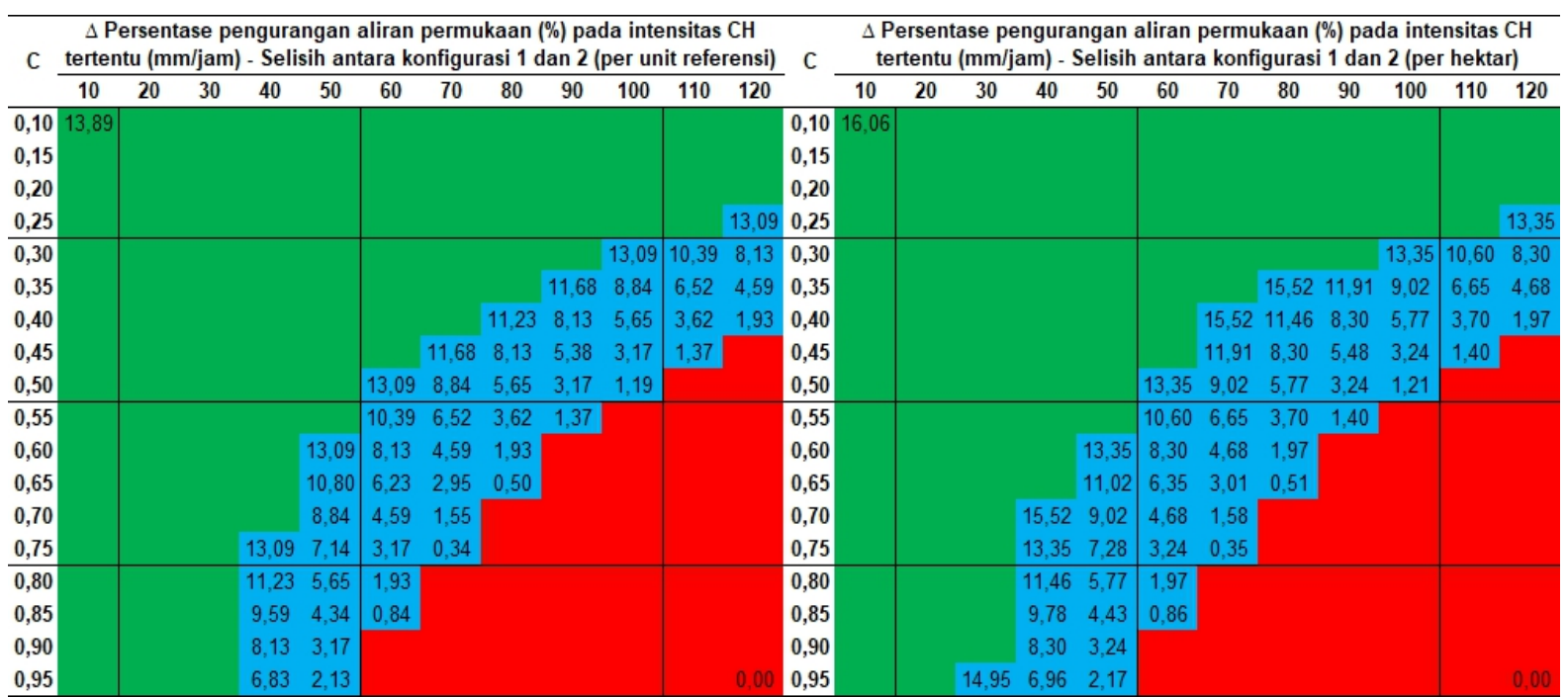

Sumber: Hasil Perhitungan (2020)

Tabel 7. Selisih antara Konfigurasi 1 dan Konfigurasi 3

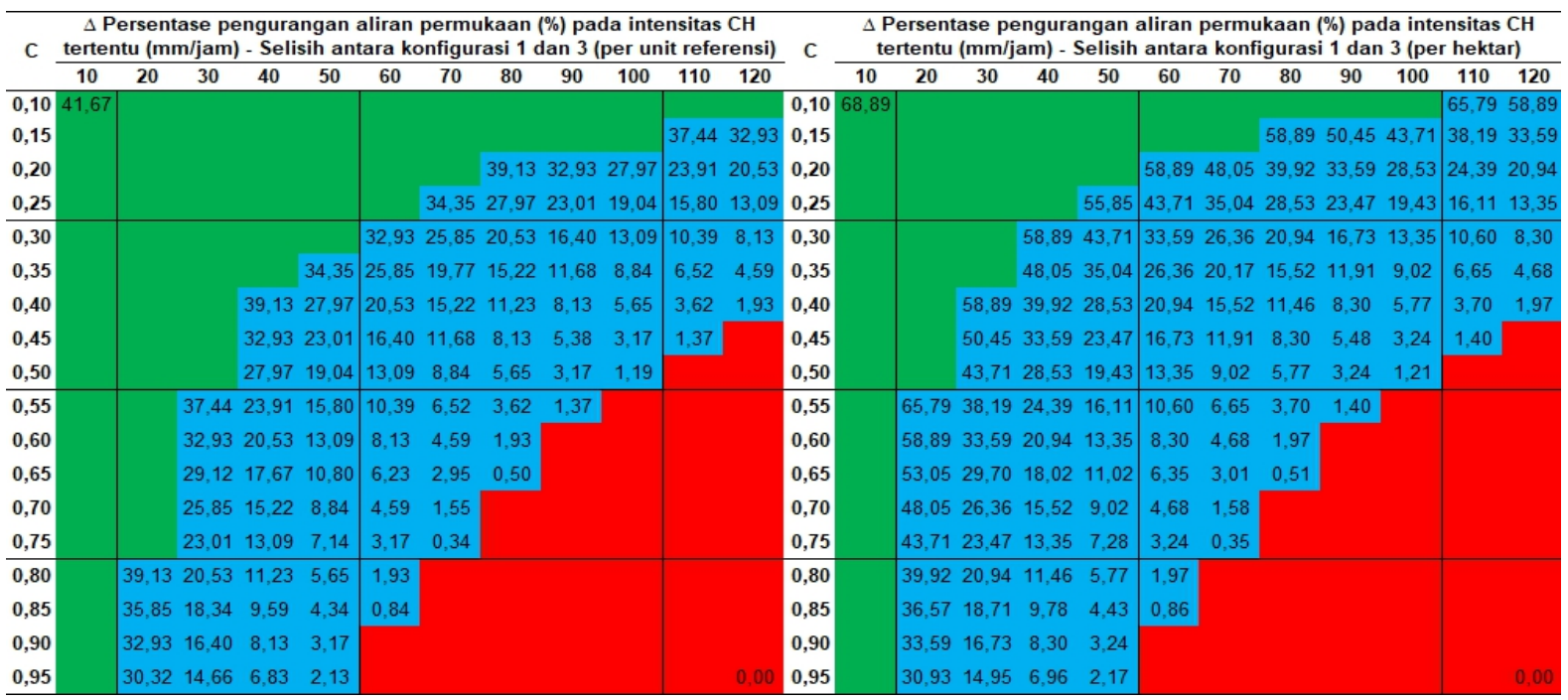


Sumber: Hasil Perhitungan (2020)

Pada Tabel 6 disajikan selisih persentase pengurangan limpasan permukaan antara konfigurasi 1 dan konfigurasi 2. Pada kondisi optimal (ditandai dengan warna hijau), konfigurasi 2 diketahui memiliki keunggulan komparatif antara $13,89 \%$ hingga $16,06 \%$ bila dibandingkan dengan konfigurasi 1. Sementara warna biru menandakan kondisi dimana nilai persentase pengurangan limpasan permukaan konfigurasi 2 lebih tinggi bila dibandingkan dengan konfigurasi 1 namun masih di bawah kondisi optimal, yakni antara $0,34 \%$ hingga $0,35 \%$ (minimal) dan antara $13,09 \%$ hingga $13,35 \%$ (maksimal). Terakhir, warna merah menandakan kondisi dimana konfigurasi 1 dan konfigurasi 2 akan menghasilkan nilai persentase pengurangan limpasan permukaan yang sama.
Pada Tabel 7 disajikan selisih persentase pengurangan limpasan permukaan antara konfigurasi 1 dan konfigurasi 3. Pada kondisi optimal (ditandai dengan warna hijau), konfigurasi 3 memiliki keunggulan komparatif antara $41,67 \%$ hingga $68,89 \%$ bila dibandingkan dengan konfigurasi 1. Sementara warna biru menandakan kondisi dimana nilai persentase pengurangan limpasan permukaan konfigurasi 3 lebih tinggi bila dibandingkan dengan konfigurasi 1 namun masih di bawah kondisi optimal, yakni antara $0,34 \%$ hingga $0,35 \%$ (minimal) dan antara $39,13 \%$ hingga $65,79 \%$ (maksimal). Terakhir, warna merah menandakan kondisi dimana konfigurasi 1 dan konfigurasi 3 akan menghasilkan nilai persentase pengurangan limpasan permukaan yang sama.

Tabel 8. Selisih antara Konfigurasi 2 dan Konfigurasi 3

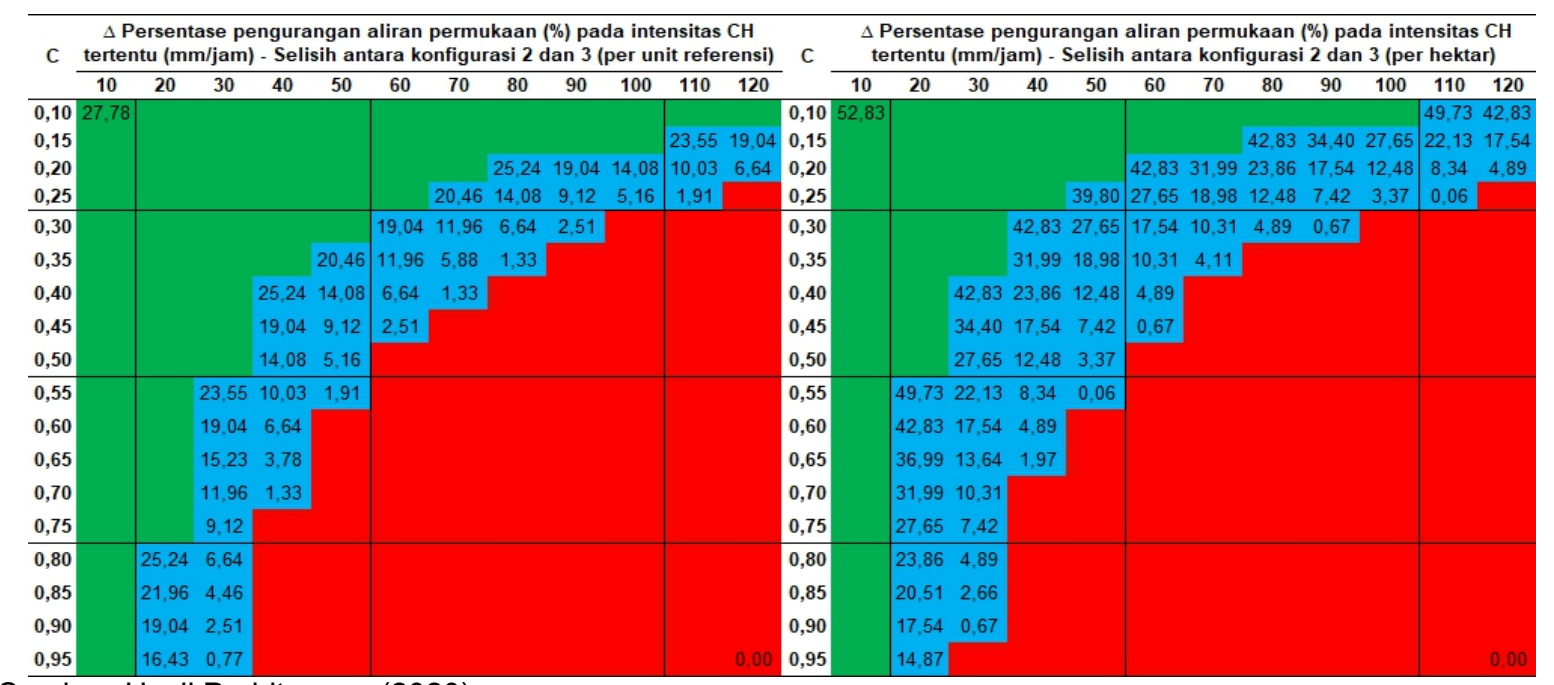

Sumber: Hasil Perhitungan (2020)

Pada Tabel 8 disajikan selisih persentase pengurangan limpasan permukaan antara konfigurasi 3 dan konfigurasi 2. Pada kondisi optimal (ditandai oleh warna hijau), konfigurasi 3 memiliki keunggulan komparatif antara $27,78 \%$ hingga $52,83 \%$ bila dibandingkan dengan konfigurasi 2. Sementara warna biru menandakan kondisi dimana nilai persentase pengurangan limpasan permukaan konfigurasi 2 lebih tinggi bila dibandingkan dengan konfigurasi 1 namun masih di bawah kondisi optimal, yakni antara $1,33 \%$ hingga $1,97 \%$ (minimal) dan antara 25,24\% hingga 49,73\% (maksimal). Terakhir, warna merah menandakan kondisi dimana konfigurasi 2 dan konfigurasi 3 akan menghasilkan nilai persentase pengurangan limpasan permukaan yang sama.
Ketiga konfigurasi rorak yang menjadi fokus dalam kajian ini diketahui memiliki persentase yang sama terhadap luas total lahan. Namun demikian, luas area tangkapan yang dilayani oleh tiap rorak secara individu tentu saja berbeda. Pada Tabel 9 disajikan jumlah rorak pada tiap konfigurasi yang melayani area tangkapan dengan luas tertentu. Pada konfigurasi 1, seluruh rorak melayani area tangkapan seluas 5,6 $\mathrm{m}^{2}$. Pada konfigurasi 2, sekitar $83,33 \%$ hingga $94,44 \%$ dari total rorak melayani area tangkapan seluas 11,2 $\mathrm{m}^{2}$. Konfigurasi 3 didominasi oleh rorak yang melayani area tangkapan dengan luas 33,6 $\mathrm{m}^{2}$ pada luasan 1 hektar. Perbedaan dalam luas area tangkapan yang berbeda ini secara logis akan menghasilkan kapasitas penangkapan air yang berbeda seperti disajikan pada Tabel 10. 
Tabel 9. Jumlah Rorak pada Tiap Konfigurasi yang Melayani Area Tangkapan dengan Luas Tertentu

\begin{tabular}{ccccccc}
\hline \multirow{2}{*}{$\begin{array}{c}\text { Luas } \\
\text { area }\end{array}$} & \multicolumn{5}{c}{ Jumlah rorak yang melayani area tangkapan dengan luas tertentu } \\
\cline { 2 - 7 } & \multicolumn{2}{c}{ Konfigurasi 1 } & \multicolumn{3}{c}{ Konfigurasi 2 } & Konfigurasi 3 \\
\cline { 2 - 7 } & Unit Referensi & $\mathbf{1 ~ H e k t a r}$ & Unit Referensi & $\mathbf{1 ~ H e k t a r}$ & Unit Referensi & 1 Hektar \\
\hline 5,6 & 102 & 306 & 17 & 17 & 17 & 17 \\
11,2 & - & - & 85 & 289 & 17 & 17 \\
16,8 & - & - & - & - & 17 & 17 \\
22,4 & - & - & - & - & 17 & 17 \\
28 & - & - & - & - & 16 & 216 \\
33,6 & - & - & $\mathbf{1 0 2}$ & $\mathbf{3 0 6}$ & $\mathbf{1 0 0}$ & $\mathbf{3 0 0}$ \\
\hline Total & $\mathbf{1 0 2}$ & $\mathbf{3 0 6}$ &
\end{tabular}

Dari Tabel 10 dapat dilihat bahwa semakin besar area tangkapan rorak yang dilayani oleh sebuah rorak, maka semakin besar pula persentase kapasitas rorak terisi seiring dengan meningkatnya intensitas hujan dan koefisien limpasan permukaan. Nilai dalam tabel tersebut disajikan dalam gradasi hijau, kuning dan merah dimana semakin besar area tangkapannya, maka penampakan tabel tersebut akan semakin didominasi oleh gradasi merah. Gradasi warna hijau yang disajikan pada tabel tersebut menandakan kondisi air hujan yang mampu ditampung oleh rorak hingga penuh pada kombinasi intensitas curah hujan dan koefisien limpasan permukaan tertentu, sementara gradasi warna kuning hingga merah menunjukkan kondisi sebaliknya.

Luas area tangkapan sebesar $5,6 \mathrm{~m}^{2}$ menunjukkan potensi untuk dapat menangkap limpasan permukaan secara optimal pada intensitas maksimum 120 $\mathrm{mm} / \mathrm{jam}(\mathrm{C}=0,45)$ dan intensitas minimum $60 \mathrm{~mm} / \mathrm{jam}(\mathrm{C}=0,95)$. Sementara luas area tangkapan sebesar $33,6 \mathrm{~m}^{2}$ hanya mampu menangkap limpasan permukaan secara optimal pada intensitas maksimum 90 $\mathrm{mm} / \mathrm{jam}(\mathrm{C}=0,10)$ dan intensitas minimum $10 \mathrm{~mm} / \mathrm{jam}(\mathrm{C}=0,95)$.

Gradasi warna hijau yang dominan pada luas area tangkapan sebesar 5,6 $\mathrm{m}^{2}$ menunjukkan potensi untuk menghasilkan persentase penangkapan limpasan yang lebih baik daripada pada luas area tangkapan sebesar 33,6 $\mathrm{m}^{2}$ yang didominasi oleh gradasi warna kuning hingga merah (akan lebih banyak menghasilkan limpasan yang tidak tertampung dalam rorak).

Namun demikian perlu diingat bahwa sebagaimana telah disajikan pada Tabel 1, luas area tangkapan per rorak untuk konfigurasi 1 adalah sebesar 5,6 $\mathrm{m}^{2}$, untuk konfigurasi 2 sebesar 10,27 hingga 10,89 $\mathrm{m}^{2}$, dan untuk konfigurasi 3 sebesar 19,6 hingga $28,86 \mathrm{~m}^{2}$. Alasan kenapa konfigurasi 1 tidak menghasilkan nilai persentase penangkapan limpasan permukaan yang paling tinggi, meskipun memiliki luas area tangkapan dengan gradasi hijau yang lebih potensial, adalah karena konfigurasi tersebut memiliki area yang tidak tertangkap oleh rorak yang lebih besar dari kedua konfigurasi lainnya. Satu-satunya jalan untuk menghasilkan nilai persentase penangkapan limpasan permukaan tertinggi pada luas area tangkapan per rorak sebesar 5,6 $\mathrm{m}^{2}$ per rorak adalah dengan membuat konfigurasi rorak baru di luar ketiga konfigurasi rorak yang dikaji dalam kajian ini dimana terdapat jumlah rorak yang lebih banyak dan jarak antar rorak yang lebih rapat.

Kajian ini menggunakan banyak simplifikasi dan asumsi bahwa bentang lahan memiliki bentuk yang seragam dimana setiap limpasan permukaan hanya akan mengalir tegak lurus searah lereng ke ketinggian yang lebih rendah. Jenis tanah, kelerengan, tutupan lahan, relief tanah dan faktor lain yang mempengaruhi koefisien limpasan permukaan tidak dikaji secara eksplisit dan hanya dinyatakan sebagai nilai koefisien limpasan permukaan (C) yang mengikuti kaidah berjenjang yakni 0,10 hingga 0,95.

Pada kondisi optimal, konfigurasi 3 memiliki keunggulan komparatif antara $41,67 \%$ hingga $68,80 \%$ (terhadap konfigurasi 1) dan antara $27,78 \%$ hingga $52,83 \%$ (terhadap konfigurasi 2). Sementara itu konfigurasi 2 memiliki keunggulan komparatif sebesar $13,89 \%$ hingga $16,06 \%$ bila dibandingkan dengan konfigurasi 1.

Dari hasil perhitungan diketahui bahwa terdapat kondisi dimana ketiga konfigurasi diketahui menghasilkan nilai yang seragam sehingga tidak ada keunggulan komparatif diantara ketiga konfigurasi tersebut. Kondisi ini umumnya berada di atas intensitas hujan 50 $\mathrm{mm} / \mathrm{jam}$ dan koefisien limpasan permukaan di atas 0,45 .

Dalam kondisi sebenarnya di lapangan, setiap bentang lahan adalah spesifik dan unik. Hasil dari kajian ini dapat digunakan sebagai 
estimasi kasar hanya apabila suatu lahan sebenarnya di lapangan sudah diketahui nilai koefisien limpasan permukaannya secara pasti maupun mengikuti metode tertentu, misalnya dari koefisien limpasan untuk metode rasional Hassing (Suripin, 2004), dan sudah diketahui secara pasti hasil analisis intensitas curah hujan untuk periode ulang tertentu. Namun demikian perlu diingat bahwa dalam kondisi dimana kedua syarat tersebut terpenuhi pun hasil kajian ini mungkin akan menghasilkan nilai yang berbeda dengan nilai sebenarnya yang hanya akan bisa didapatkan dari percobaan aktual di lapangan.

Tabel 10. Persentase Kapasitas Rorak Terisi pada Luas Area Tangkapan Tertentu yang Dilayani oleh Tiap Rorak

\begin{tabular}{|c|c|c|c|c|c|c|c|c|c|c|c|c|c|c|c|c|c|c|c|c|c|c|c|c|c|c|c|}
\hline \multirow{2}{*}{ 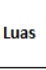 } & & \multicolumn{12}{|c|}{ Persentase Kapasitas Rorak Terisi (\%) pada Intensitas CH tertentu (mm/jam) } & & & \multicolumn{12}{|c|}{ Persentase Kapasitas Rorak Terisi (\%) pada Intensitas CH tertentu (mm/jam) } \\
\hline & & 10 & 20 & 30 & 40 & 50 & 60 & 70 & 80 & 90 & 100 & 110 & 120 & & & 10 & 20 & 30 & 40 & 50 & 60 & 70 & 80 & 90 & 100 & 110 & 120 \\
\hline \multirow[t]{13}{*}{60} & 0 & 1,87 & 3 & 50 & 47 & 33 & 1,20 & 13,07 & 14,93 & 16,80 & 18,67 & 20,53 & 22,40 & & 0,10 & 7,47 & 14,93 & 22,40 & 29,87 & 37,34 & 44,80 & 52,27 & 59,74 & 67,21 & 4,67 & 2,14 & 9,61 \\
\hline & 5 & 2,80 & 50 & 40 & 20 & 14,00 & 16,80 & 60 & 40 & 25,20 & 28,00 & 30,80 & 33,60 & & 51 & 11,20 & 22,40 & 33,60 & 44,80 & 56,00 & 67,21 & 1 & 89,61 & 0,81 & & 23,21 & \\
\hline & 0,20 & 3 & 17 & 1,20 & 14,93 & 18,672 & 22,402 & 14 & 29,87 & 33,60 & t & 41,07 & 44,80 & & 0,201 & 14,93 & 29,87 & 44,80 & 59,74 & 74,67 & 89,61 & 104,54 & 119,48 & 134,41 & 149,35 & 28 & 179,21 \\
\hline & 0,25 & 4,67 & 33 & 1,00 & 18,67 & 23,34 & 28,00 & 32,67 & 37,34 & 42,00 & 46,67 & 51,34 & 56,00 & &, 251 & 18,67 & 37,34 & 56,00 & 74,67 & 93,34 & 112,01 & 130,68 & 149,35 & 168,01 & 186,68 & 05,35 & 24,0 \\
\hline & 30 & 5,60 & 20 & 16,80 & 22,40 &, 00 & $3,60 \quad 3$ & 39,20 & 44,80 & 50,40 & 56,00 & 61,60 & 67,21 & & 302 & 22,40 & 44,80 & 67,21 & $89,61 \quad 1$ & 112,01 & 134,41 & 156,81 & 179,21 & 201,62 & 224,0 & 6,4 & 8,82 \\
\hline & 45 & 8,40 & 80 & 25,20 & 33,60 & 42,00 & $0,40 \quad 5$ & 58,80 & 67,21 & 75,61 & 84,01 & 92,41 & 100,81 & & 0,45 & 33,60 & $67,21 \quad 1$ & 100,811 & 134,41 & 168,012 & 201,62 & 235,22 & 268,82 & 302,42 & 336,03 & 369,63 & 403,2 \\
\hline & 0,50 & 9,33 & 67 &, 00 & 37,34 & 46,67 & 56,00 & 65,34 & 74,67 & 84,01 & 93,34 & 102,67 & 1 & & 0,503 & 37,34 & $74,67 \quad 1$ & 112,011 & 149,35 & 186 & 2 & 261,352 & 298,69 & 03 & 373,36 & 70 & 448,0 \\
\hline & 55 & 10,27 & ,53 & 80 & 41,07 & 51,34 & 61,607 & 71,87 & 82,14 & 92,41 & 102,671 & 7112,94 & 123,2 & & 0,554 & 41,07 & 82,141 & 123,21 & 164,282 & 205,352 & 246,42 & 287,493 & 328,56 & 369,63 & 410,70 & 451,77 & 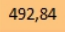 \\
\hline & 50 & 11,20 & 40 & 33,60 & 44,80 & 56,00 & 67,21 & 78,41 & 89,61 & 100,81 & 112,011 & 123,21 & 134,41 & & 0,60 & 44,80 & $89,61 \quad 1$ & 134,411 & 179,212 & 224,022 & 268,82 & 313,633 & 358,43 & 403,23 & 448,04 & 492,84 & 537,6 \\
\hline & 65 & 12,13 & 27 & 36,40 & 48,54 & 60,67 & 72,81 & 84,94 & 97,07 & 109,21 & 121,341 & 133,48 & 145,61 & & 0,654 & 48,54 & 97,071 & 145,611 & 194,152 & 242,692 & 291,22 & 339, & 88 , & 6,83 & 485,37 & 533,91 & 582,4 \\
\hline & 85 & 15,87 & 31,74 & 47,60 & 63,47 & 79,34 & $\begin{array}{lll}95,21 & 1\end{array}$ & 111,08 & 126,94 & 142,81 & 158,681 & 174,55 & 190,42 & & 0,85 & 63,471 & 126,941 & 190,422 & 253,893 & 317,363 & 380,83 & 444,305 & 507.77 .5 & 571,25 & 634,72 & 698,19 & 761. \\
\hline & 0 & 16,80 & 33,60 & 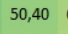 & $\varepsilon$ & 011 & 100,811 & 117,61 & 1 & 1 & 1 & 2 & 201,62 & & 06 & 67,211 & 2 & 20 & 26 & 33 & 40 & 4 & 5376 & 85 & 672,05 & 26 & 806 \\
\hline & 95 & 17,73 & 35,47 & 53,20 & 70,94 & $88,67 \quad 1$ & 106,411 & 124,14 & 141,88 & 159,61 & 177,351 & 195,082 & 212,82 & & 0,957 & 70,941 & 141,882 & 212,822 & 283,763 & 354,704 & 425,63 & 496,575 & 567,51 & 638,45 & 709,39 & 780,33 & 851 \\
\hline 11, & & 3,73 & 7,47 & 11,20 & 14,93 & 18,67 & 22,40 & 26,14 & 29,87 & 33,60 & 37,34 & 41,07 & 44,80 & & 0,10 & 9,33 & 18,67 & 28,00 & 37,34 & 46,67 & 56,00 & 65,34 & 74,67 & 84,0 & 93,34 & 102 & 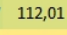 \\
\hline & 5 & 5,60 & 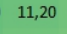 & in & 0 & 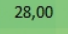 & 33,60 & 39 & 0 & 50 & 0 & 61,60 & 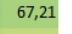 & & 0,15 & 14,00 & 10 & 42,00 & 56,00 & 70, & 01 & 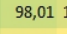 & 1120 & 1 & 01 & 1 & \\
\hline & 0,20 & , 47 & 93 & 40 &, 87 & 37,34 & 44,80 & 52,27 & 59,74 & 67,21 & 74,67 & 82,14 & 89,6 & &, 20 & 18,67 & 37,34 & 56,00 & 74,67 & 93,341 & 112,01 & 130,68 & 149,35 & 168 & 186,68 & $3 \quad 205,35$ & \\
\hline & 0,25 & 9,33 & 18,67 & 28,00 & 37,34 & 46,67 & 56,00 & 65,34 & 74,67 & 84,01 & 93,34 & 102,67 & 112,01 & & 0,25 & 23,34 & 46,67 & 70,01 & 93,341 & 116,681 & 140,01 & 163,35 & 186,68 & 210 & 233,35 & 256,69 & 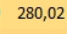 \\
\hline & 0 & 11,20 & ) & 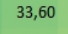 & 80 & 00 & 21 & 78,41 & . 89, & 1 & 11 & 1 & 134 & & D & 28,00 & 10 & 84,01 & 11 & 14 & 16 & & & & 22 & 2 & \\
\hline & 5 & 13,07 & 14 & 0 & 27 & 4 & 78,41 & 91,47 & 104 & 117 & 130 & 14 & 156 & & & 32,67 & 65,34 & 98,01 & 130,681 & 16 & 19 & & & & 9 & & \\
\hline & 0,40 & 14,93 & 29,87 & 44,80 & 59,74 & 74,67 & 89,611 & 104,54 & 119,48 & 134,41 & 149,35 & 164,28 & 179 & & 0,40 & 37,34 & 74,671 & 112,01 & 149,351 & 186,682 & 224,02 & 261,35 & 298,69 & 336 & 373,36 & 410,70 & 44 \\
\hline & 0,45 & 16,80 & 60 & 40 &, 21 & 84,011 & 100,811 & 117,61 & 134,41 & 151,21 & 168,01 & 184,81 & 201, & & 15 & 42,00 & 84,011 & 126,011 & 168, & 210 & 25 & 29 & 336 & & 120,03 & 3462 & \\
\hline & 0,85 & 31,74 & 63,47 & 21 & 12 & 15 & 190 & & 25 & 28 & & & & & & 79,34 & 15 & 238 & & & & & & & 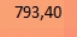 & & \\
\hline & 0,90 & 33,60 & 67,21 & 811 & 134,41 & 168,012 & 201,622 & 22 & 268 & 302 & 33 & 369,63 & 403,23 & & 90 & 84,01 & 168,012 & 252,023 & 336,034 & 42 & 45 & 588,05 & 672,05 & 756,06 & 840,07 & 924,07 & \\
\hline & 95 & 35,47 & 70,94 & 5,41 & 141,881 & 177,352 & 212,822 & 248,29 & 283,76 & 319,23 & 354,70 & 390,164 & 42 & & 95 & 88,67 & $177,35 \quad 2$ & 266,023 & 354,704 & 44 & 046 & 727 & 709,39 & 798,06 & 74 & 497 & \\
\hline & & & & & & & & & 0 & 0 & & 0 & & & & 0 & & & 305 & & & & & & & & \\
\hline & 0,15 & 8,40 & 80 & 20 & 33,60 & 005 & 405 & 58,80 & 67,21 & 75,61 & 84,01 & $\begin{array}{lll}92,41 & 1\end{array}$ & 100,8 & & 0,15 & 16,80 & $33,60 \quad 5$ & 50,40 & $\begin{array}{lll}67,21 & 8\end{array}$ & $84,01 \quad 1$ & 311 & 11 & 1 & 21 & 1 & 81 & \\
\hline & 0,20 & 11,20 & 22,40 & 60 & 44,80 & 56,00 & 67,217 & 78,41 & 89,61 & 100,81 & 112,01 & 123,21 & 13 & &, 202 & 22,40 & $44,80 \quad 6$ & $67,21 \quad 8$ & $89,61 \quad 1$ & 112,011 & 134,411 & 156,81 & 179,21 & 201,62 & 224,02 & 246,42 & 2 \\
\hline & & 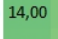 & & & & & & t & 11 & 1 & 1 & 1 & & & & 0 & 8 & 11 & 1 & & & & & & & & \\
\hline & 0,30 & 16,80 & 33,60 & & 21 & 011 & 1 & & 13 & 15 & 168 & 184 & & & 103 & 33,60 & 11 & 100,811 & & & & & & & & & \\
\hline & 0,35 & 19,60 & 20 & 10 & 78,41 & 98,011 & 11 & 1 & 15 & 17 & 19 & 2 & 23 & & 353 & 39,20 & $\begin{array}{lll}78,41 & 1\end{array}$ & 117,611 & 1 & 22 & & 23 & 3 & 83 & 392,03 & 23 & \\
\hline & & 22,40 & 4 & & 1. & 011 & & & & & 2 & 24 & & & 04 & 44,80 & 89,61 & 411 & 2 & 2 & 26 & 33 & 35 & 4 & 44 & 452,04 & \\
\hline & 5 & 25 & 5 & 1 & 11 & & & & & & & & & & & 50,401 & 100 & & & & & & & & & & \\
\hline & 50 & 28,00 & 56,00 & & & & & & & & & & & & 05 & 001 & & 16 & & & & & & & 5 & 05 & \\
\hline & 5 & 30,80 & 61,60 & 11 & 211 & & & & 24 & 27 & 30 & 3 & 36 & & & 61,601 & 123,21 & 812 & 23 & 23 & & 34 & 45 & & 61 & $01 /, 05$ & \\
\hline & 60 & 33 & 1 & 811 & 11 & 12 & 22 & 22 & 23 & 23 & 33 & 4 & 40 & & 06 & 67,211 & 412 & 26 & 33 & 4 & 134 & 145 & 4 & 85 & 672,05 & 739,26 & 000 \\
\hline & & & & & & & & & & & & & & & & 11 & & & & & & & & & & & \\
\hline & & 39,20 & 1 & & & & & & 31 & 35 & & & & & & 78,411 & & & & & & & & & & & \\
\hline & ,75 & 42,00 & 84 & 011 & 168,012 & 210,022 & 22 & 23 & 336,033 & 378,034 & 42 & 46 & 50 & & 58 & 84,01 & 168,012 & 252,02 & 336,0342 & 035 & 045 & 05 & 672,05 & 756,06 & 840,07 & 924,07 & 100 \\
\hline & 2 & 44,80 & 8 & & & & & & & & & & & & 08 & 89,61 & 179,212 & 235 & 344 & & & & & 6 & 7 & 8 & \\
\hline & & & 95 & & & & & & & & & & & & & & & & & & & & & & & & \\
\hline & & se & 100 & & & & & & & & & & & & & 100,812 & $623 \mathrm{c}$ & 4240 & 2350 & 046 & 604,857 & 668 & $46 \mathrm{~s}$ &, 271 & 1008,081 & . & 12 \\
\hline & -1 & & - & & & & & & & & & & & & & & & 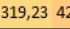 & -1 & 0 & & -1 & 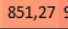 & -5 & -5 & -1 & \\
\hline
\end{tabular}

Sumber: Hasil Perhitungan (2020) 


\section{KESIMPULAN DAN SARAN}

Namun demikian, konfigurasi 3 diketahui memiliki lebih banyak keunggulan komparatif dibandingkan dengan kedua konfigurasi lainnya. Hal ini menjadikan konfigurasi 3 lebih tepat untuk diaplikasikan dalam mengoptimalkan penangkapan air hujan khususnya pada karakteristik curah hujan yang tidak terlalu tinggi dan koefisien limpasan permukaan yang berada di bawah 0,70 .

Sebagai saran, penelitian ini perlu untuk diuji di lapangan mengingat parameter yang sudah jelas sehingga hanya kondisi spesifik di lapangan yang akan membedakan hasilnya. Fokus untuk penelitian selanjutnya adalah mendapatkan nilai pengurangan limpasan permukaan aktual untuk konfigurasi 3 di lapangan, mengikuti kaidah percobaan seperti yang dilakukan oleh Noeralam et al. (2003) yakni dengan menggunakan petak percobaan lapangan yang dilengkapi oleh drum penampung aliran permukaan.

Pengukuran kadar air tanah menggunakan sensor kadar air tanah seperti yang dilakukan oleh Wirasembada et al. (2017) dapat pula diaplikasikan untuk mengukur kondisi penyerapan aktual dalam rorak, khususnya konfigurasi 3. Selain itu, sebagai kelanjutan dari penelitian ini juga akan dilakukan kajian resapan rorak aktual di lapangan menggunakan konfigurasi rorak 3 dalam hubungannya dengan produktivitas tanaman tertentu seperti yang dilakukan oleh Surdianto et al. (2012).

\section{PERSANTUNAN}

Tulisan ini merupakan lanjutan dari kegiatan Kajian Pemanfaatan Lahan Kering di Kabupaten Pandeglang pada tahun 2016. Penulis menyampaikan terima kasih kepada Ir. Hasmana Soewandita, M.S., Ir. Nana Sudiana, M.Si dan Ir. Eko Widi Santoso, M.Si atas dukungan selama penulisan naskah.

\section{DAFTAR PUSTAKA}

Arsyad, S. 2010. Konservasi Tanah dan Air (Edisi Kedua). Penerbit IPB Press. Bogor

Brown, C., J. Gerston dan S. Colley. 2005. Texas Manual on Rainwater Harvesting, Third Edition. Texas Water Development Board. Austin, Texas. 88p.
Chow, V.T., D.R. Maidment, L.W. Mays. 1988. Applied Hydrology. McGraw-Hill. New York.

Fachruddin, B.I. Setiawan, Prastowo dan Mustafril. 2015. Pemanenan Air Hujan Menggunakan Konsep Zero Runoff System (ZROS) dalam Pengelolaan Lahan Pala Berkelanjutan. Jurnal Teknik Sipil, Vol 22(2): 127-136.

Noeralam, A. 2002. Teknik Pemanenan Air yang Efektif dalam Pengelolaan Tanah pada Usaha Tani Lahan Kering, (Disertasi Doktoral), Institut Pertanian Bogor.

Noeralam, A., S. Arsyad, dan A. Iswandi. 2003. Teknik Pengendalian Limpasan permukaan yang Efektif pada Usahatani Lahan Kering Berlereng. Jurnal Tanah dan Lingkungan, Vol 5(1): 13-16

Raharjo, A.P., 2019. Simulasi Pengurangan Limpasan Permukaan Menggunakan Sistem Pemanenan Air Hujan Sederhana di Kawasan Penyangga Perkotaan. Jurnal Alami, 3(1): 32-42.

Republik Indonesia. 2014. Undang-Undang Nomor 37 Tahun 2014 tentang Konservasi Tanah dan Air. Lembaran Negara RI Tahun 2014, Nomor 299. Sekretariat Negara: Jakarta.

Surdianto, Y. 2012. Analisis Kecukupan Air di Kebun Belimbing Manis (Averrhoa carambola L.). Disertasi Doktoral, Institut Pertanian Bogor.

Surdianto, Y., B.I. Setiawan, Prastowo dan S.K. Saptomo. 2012. Peningkatan Resapan Air Tanah dengan Saluran Resapan dan Rorak untuk Meningkatkan Produktivitas Belimbing Manis (Studi Kasus di Kota Depok). Jurnal Irigasi 7(1): 1-15.

Suripin. 2004. Sistem Drainase Perkotaan yang Berkelanjutan. Penerbit Andi. Yogyakarta

Wirasembada, Y.C., B.I. Setiawan dan S.K. Saptomo. 2017. Penerapan Zero Runoff System (ZROS) dan Efektivitas Penurunan Limpasan Permukaan pada Lahan Miring di DAS Cidanau, Banten. Media Komunikasi Teknik Sipil, 23(2): 102-112 